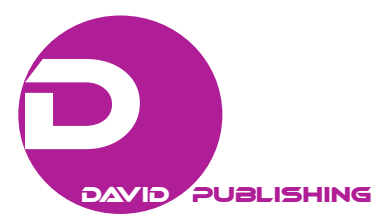

\title{
The Role of Strategic Communication for Organ Donations
}

\author{
Zeitel-Bank Natascha \\ Management Center Innsbruck, Innsbruck, Austria
}

\begin{abstract}
One big achievement in the last decade is the rapid development in transplantation medicine, enabling seriously ill people to live longer. However, in the year 2014, 12 people in the European Union have died every day because of the lack of available organs. Nearly, 70,000 people were waiting for a matching graft. An analysis of donation and transplantation variation across the European member states shows that since many years, Spain occupies a pioneer role, whereas Germany and Austria are lagging behind. From the legal and administrative perspective, Spain and Austria are quite similar with their presumed consent system (opting out), whereas Germany has an informed consent system (opting in). Hence, there must be other influencing factors like the way of multilevel communication leading to the following research question: How does multilevel communication influence organ donations in Spain, Germany, and Austria? On the basis of a cross-country study, it can be shown that strategic communication on the (inter)personal and organizational level supported by the creation of public awareness on the national level is crucial for succeeding in closing the gap between demands and realized organ transplantation.
\end{abstract}

Keywords: organ donations, organ transplantation, strategic communication, Spanish model, cross-country study

\section{Introduction}

Organ transplantation can be viewed as one of the biggest achievements in medicine. However, the demand for organs exceeds their availability. With focus on the European Union, it can be stated that an average of 12 people die each day because of the lack of available organs; 70,000 people were waiting for a matching graft in 2014 (Council of Europe, 2014). The scale of the demand for donor organs is even bigger in reality. Due to the permanent rising life expectancy, new technologies and chronic diseases like diabetes and hypertension, the demand for organs, tissues, and cells is continuously rising (Council of Europe, 2013). With an increase in transplantation, not only the quality of life of the patient would be improved massively, but also the health care systems could save expenditures due to less costly transplantations in the long run compared to permanent dialysis, for example (Lippincott Williams \& Wilkins, Inc., 2011, p. 30). An analysis of donation and transplantation across the European Union shows that there are considerable differences. ${ }^{1}$ With 35.9 postmortal organ donors per million population (pmp), Spain is not only the country with the most organ donors in the European Union (EU) but also worldwide ${ }^{1}$ (Deutsche Stiftung Organtransplantation—DSO, n.d.a;

\footnotetext{
* This article is an extended and modified version of a presentation held at the International MakeLearn Conference on ${ }^{\text {Managing }}$ Intellectual Capital and Innovation for Sustainable and Inclusive Society' together with Anja Pickel, MA.

Zeitel-Bank Natascha, prof./Ph.D., Management Center Innsbruck (MCI), Innsbruck, Austria.

Correspondence concerning this article should be addressed to Zeitel-Bank Natascha, Management Center Innsbruck Universitaetsstrasse 15, 6020 Innsbruck, Austria.

${ }^{1}$ Spain (35.9), Croatia (35.1), Portugal (27.7), USA (27.0), Belgium (26.8), Austria (25.5), France (25.3), Italy (23.1), Slovenia (22.8), Great Britain (20.4), Australia (16.1), The Netherlands (16.1), Poland (15.4), Estonia (15.2), Switzerland(14.1), and Germany (10.7).
} 
Rudge, Matesanz, Delmonico, \& Chapman, 2012, p. 50). Among countries with lower organ donation rates are: Austria with $25.5 \mathrm{pmp}$ in the middle field and Germany with only $10.7 \mathrm{pmp}$ worldwide at the bottom line. Comparing those data over the years, it can be seen that Spain keeps a considerable distance to Austria and Germany. In these three countries, different regulatory frameworks prevail; Spain and Austria have an opt-out system (presumed consent), whereas Germany has an explicit or informed consent system (opt-in approach). Informed consent requires that every citizen has to make, at least one time in life, an official statement with respect to their organ donation status (DSO, 2012, p. 4). According to the literature, there is no clear evidence that an opt-out system is the only factor which influences the amount of organ donations. Even within a country which has the same regulatory framework huge local differences. Furthermore, all three countries have a strong federal structure with one national organisation that is in charge of the general coordination which is seen as an advantage (Matesanz, Domínguez-Gil, Coll, De la Rosa, \& Marazuela, 2011). In Spain, the "Organización Nacional de Transplant" (ONT) is an institution belonging to the Spanish Ministry of Health, Social Services and Equality; in Germany, the private organization DSO with a strong involvement of national and regional authorities; and in Austria, the "ÖBIGTranplant" is an administrative part of the Austrian National Institute of Health. However, in the context of family involvement studies revealed that there is a connection between the families' satisfaction, the degree of medical attention received in the hospital, and the attitude towards organ donation (Martínez, López, Martín, Scandroglio, \& Martín, 2001, pp. 404-417). If the experience is a positive one, the decision-making of the family will be influenced in an equally positive manner. The same applies for the opposite case as well. The conversation with family members is in a supportive way, the thoughtful choice of a calm and private location for the donation enquiry and the prevention of pressure during the decision making process of the family tends to have a very positive impact. Furthermore, the general knowledge based on the creation of a national awareness seems to play another crucial role (Siminoff, Traino, \& Genderson, 2015, pp.1-9).

\section{Research Design}

As the legal perspective with the opt-in/opt-out possibility and also the strong decentralized regional structure in all three countries can't be the only influencing factors, there is the central assumption that other aspects, like communication, play a crucial role. Strategic communication is a basis for transferring information to the respective stakeholder, like regional and local health care experts in charge, donors and their families in a comprehensive way. Communication also forms the basis for creating knowledge and a positive attitude in the society based on awareness and trust. Misunderstandings, fear, and insecurity can be reduced and even avoided. Thus, the focus of this study lies on the way of multilevel communication between the respective stakeholders (potential organ donors, families, doctors, and the general awareness of the public) leading to the following research question: How does multilevel communication influence organ donations in Spain, Germany, and Austria? In this context, strategic communication uses multiple tools on the respective levels and includes talks with various groups of people. "The strategy of choice in a competitive environment is proactive, two-way communication, in which organizations plan for and initiate relationships with the people important to their success. This approach emphasizes dialogue over monologue" (Smith, 2013, p. 11). On the basis of a systematic literature review, the following cross-country comparison will first identify the way of communication on the (inter)personal and organizational level and in a second step on the national level. Similarities and differences between the examined countries will be illustrated and respective recommendations are provided. 


\section{(Inter)Personal and Organizational Structure}

\section{Spain}

The essential characteristic of the Spanish model is the decentralized structure with its three levels of coordination: the Spanish National Transplant Organization (OND) was founded in 1989, the regional level (in total 17) and the local hospital level (Bouwman, Lie, Bomhoff, \& Friele, 2013, p. 117). Each hospital, which has an Intensive Care Unit (ICU) or acute beds and the allowance to procure organs as well as tissues, has an in-house transplant coordination team consisting in most cases of intensive care physicians or anaesthesiologists, who also work as part-time internal coordinators. This gives the advantage of pursuing the genuine profession while being present as transplant coordinator even in small hospitals (Matesanz, 2003, p. 737). The in-house coordinator is independent but interconnected with national and regional coordinators. This person is responsible for the creation of a donor detection program and for a transformation of potential donors into actual donors through an early identification process (Matesanz et al., 2011, p. 335). In-house transplant coordinators have a major advantage in comparison to external ones in that they are familiar with the intensive care unit conditions. They have professional insight as well as authority, thereby reducing potential donor losses. In Spain, the person automatically becomes an organ donor in case of no expressed refusal. However, in every single case, the family is contacted and consulted. If the affiliated parties refuse the donation request, this decision will be respected (Gevers, Janssen, \& Frield, 2004, p. 180). This underlines the importance of training in how to conduct a conversation properly. Therefore, those who in-house transplant coordinators have the opportunity to follow an initial training and regular seminars, also open to other employees in the transplant unit (Bouwman et al., 2013, p. 117). The communication training model concentrates on identification of stress reactions of family members, emotional stabilization, and informing family members as well as making an active contribution to agreement (Poepplein, 2012, p. 524; Rodríguez-Arias, Wright, \& Paredes, 2010, p. 1109). A Spanish survey revealed that $78 \%$ of 200 concerned families changed their mind and expressed consent for donation after they received an explanation regarding the organ donation process, which highlights the success of the communication trainings for health professionals (Spooner, 2003, p. 952). It is important that the entire hospital has a positive attitude towards donation to ensure a smooth process (Rudge et al., 2012).

\section{Germany}

Similar to Spain, Germany has an organisation that overviews and coordinates the deceased donation and transplantation issues on a nationwide scope. The private non-profit foundation of organ transplantation (DSO) was founded in 1983 and has been assigned by the German Ministry of Health to manage donation and procurement activities (DSO, n.d.b; Global Observatory on Donation and Transplantation, 2006). The DSO organises the necessary collaboration for the organ removal and all further activities that are necessary for the transplantation process. The organ allocation is, however, not organised through Eurotransplant, a cooperation of eight European countries (Eurotransplant, n.d.). Germany is divided into seven local organ donation regions, which should facilitate an immediate help to the single concerned hospitals (DSO, 2014). The so-called transplant coordinators are deployed at national, regional, and local level. Hospitals, in which organs are removed, are obliged to have at least one trained transplant hospital coordinator. In practice, this transplant coordinator is often in charge of more hospitals, which means that in reality there is often no one transplant coordinator for each hospital. Their major tasks include organizing organ donations, executing donor evaluations, interlocution with family members, conducting information events on the issue of organ donation and the support and guidance of 
hospitals within the scope of organ donation, and the operation theatre management (DSO, n.d.b). It can be assumed that because of the dislocation of those coordinators from one single hospital (in contrast to the Spanish in-house transplant coordinators), the communication with the families is one important part for organ donation suffers: In the year 2013, the family refusal rate has been $31.53 \%$. This means that from 1,275 asked next of kin 402 refused organ donation (DSO, 2014, p. 47). This could be explained by the fact that only $35 \%$ of the intensive care staff, who normally lead the interlocution with the family members have ever participated in a communication seminar (Poepplein, 2012, p. 524).

\section{Austria}

Like in Spain and Germany, the Austrian organ donation and transplantation system is a three-tier coordination system with a national, regional, and local level (Bouwman et al., 2013, p. 27). With the foundation of the "ÖBIG-Transplant" under the authority of the Austrian Federal Institute for Health Care (Österreichisches Bundesinstitut für Gesundheitswesen) in the year 1991, Austria has a public institution, which coordinates, implements, and evaluates the donation and transplantation activities on a nationwide and international scope, e.g. maintaining the opting-out registry (ÖBIG-Transplant, n.d.). An important part of the ÖBIG-Transplant is the transplantation advisory council which consists of experts and lobbyists from the transplant and healthcare area. Austria's nine federal states are combined into five care regions, namely, region North, South, West, and two times East (Bundesministerium für Gesundheit und Frauen, 2016, p. 36). For each of the five regions, there is a so-called regional transplantation advisor (TX advisor). The major task of this TX advisor is to support the donor hospitals with the announcement and the care of the possible donor and to help with the communication between donor hospital and transplantation centre. Furthermore, the TX advisor is in charge of the establishment of the so-called local transplantation representatives (LTXB) and of the communication and educational seminars for the coordinators. The 28 local coordinators have been implemented between 2009 and 2013, especially in those hospitals with a high possibility of caring for possible organ donors respectively in specialised hospitals. The LTXB, who usually works in the intensive care unit, is the person responsible for the process and all issues around the subject organ donation and transplantation in the hospital. So Austria has regional as well as local transplant coordinators, who should receive educational trainings on a regular basis (Bundesministerium für Gesundheit und Frauen, 2016, p. 36). Like in Spain also in Austria, according to the legislation, relatives have in theory no authorisation to reject the organ donation of a family member and are not entitled to be informed in the event of a planned organ explanation. In practice, however, it looks slightly different because the existing law is not strictly adhered to Gevers et al. (2004, pp. 177-178) who state that despite the strict presumed consent, family members are normally asked for their consent when there is no registration of the refusal of the deceased person. However, a study of 2008 illustrated that from 158 interviewed family members asked for consent regarding organ donation of a deceased next of kin more than half of them (53\%) refused the request. Another study shows a refusal rate of about 33.54\% (Bouwman et al., 2013, p. 26).

\section{Information and Public Awareness on the National Level}

\section{Spain}

In Spain, the awareness of organ donation is created through direct media involvement. Media attention has always been a priority, knowing that this information is transmitted directly to the society as a whole (ONT, n.d.). Since the creation of the ONT in 1989 , the donation rate has increased by almost $250 \%$ without significant 
advertising campaigns (Australian Government, 2013). Instead there is an active and strong press involvement building connections with journalists through press releases, newsletters, and press meetings. Each year, the national authority conducts a training seminar in organ donation for journalists to provide first-hand information. These principles have led the media in Spain to handle information about donation and transplantation appropriately (Australian Government, 2013). In addition, in-house coordinators are also increasingly involved in areas like "promotion, training, education, relation with mass media, management of resources, research" (Matesanz et al., 2011, p. 335). In this way, a positive attitude towards organ donation is communicated to the Spanish public through the dissemination of positive news and creation of general awareness, also supported by a 24-hour telephone line for consultation (ONT, n.d.). However, there is still room for improvement: A study (Febrero, Ríos, Martínez-Alarcón, López-Navas, Sánchez, Ramis, \& Parrilla, 2013, pp. 3586-3587) examined the knowledge of adolescents in the southeast of Spain with respect to the concept of brain death. There exists an association between the lack of knowledge about brain death and the fear of being wrongly declared dead as a psychosocial barrier to a positive attitude towards organ donation and transplantation: $38 \%$ of the surveyed adolescents knew about the brain death concept, whereas the majority with 54\% did not know it, and 8\% thought that brain death is not considered to be the factual death of a person. Those teenager who had knowledge about the brain death concept, had in general a more positive attitude towards deceased organ donation compared to those who had no or a false knowledge about the brain death concept. This highlights how communication influences the attitude towards donation in a favourable way and therefore, it can have an impact on future organ donation rates.

\section{Germany}

In Germany, the informed consent system has been amended in November 2012 by emphasising the importance of an informed decision regarding organ donation (DSO, 2012, p. 4; Bundeszentrale für gesundheitliche Aufklärung, n.d.). Thus, all Germans aged 16 or older will regularly be approached by their health insurers and encouraged to think about organ donation and to complete an organ donor card. For the first time, the amendment explicitly states that organ donation shall be promoted. A free of charge telephone hotline for the general public but also for health professionals has also been installed. The new legislation requires hospitals and clinics to have transplant advisers who can reach out to family members of the injured or deceased, and ask them what the person's wishes were (Gevers et al., 2004, p. 179; DSO, 2014, p. 19; Bundeszentrale für gesundheitliche Aufklärung, 2012, pp. 16-21). However, also two years after the amendment, a survey of the Federal Health Centre for Health Education conducted in 2014 revealed that from 4,002 interviewed persons between 14 and 75 years, more than the half (57\%) are badly informed about organ donations, and $38 \%$ are well or very well informed (5\%). Most of the fears are connected with misuse, unfair distribution, or an insufficient treatment (in case of possession of a donor card). Even if there exists a general positive attitude towards organ donations ( $80 \%$ ), and $64 \%$ are keen to help; only $35 \%$ of the surveyed persons have a donor card. Another important finding is that $44 \%$ of the interviewed persons have not received any information from their statutory health insurers about this topic or can't remember it (13\%) (Bundeszentrale für gesundheitliche Aufklärung, 2014). In 2014, the German Ministry of Health together with the Federal Centre for Health Education launched a campaign "I decide" ("Ich entscheide") for creating general public awareness. This includes measures in offline and online media channel supported by testimonials like actors and sportspersons (Ärzte Zeitung, 2014). 


\section{Austria}

In Austria, ÖBIG-Transplant as well as the adherent coordination offices are not only responsible for implementing, evaluating, but also for promoting organ and stem cell donation. "These activities are aimed at providing the best possible services for Austria's residents while ensuring high quality levels" (ÖBIG-Transplant, n.d.). However, there is no expressed and visible approach to the media or the public in a regular way. This situation can be described as a complete lack of a national strategic communication policy that regulates and determines how to properly deal with the mass media in general, including the delivery of information to the public.

\section{Results and Discussion}

All three countries have a decentralized administrative structure with a strong coordination organization on the national level, which is an advantage in the overall multilevel communication process. However, Spain and Germany deploy their transplant coordinators on a local, regional, and national level, whereas Austria deploys them only on a regional and local level, which might be a disadvantage. In Spain, there are much more in-house transplant coordinators than that of Germany and Austria, who unburden the normal hospital staff and can dedicate their work to organ donation in the clinics. Approaching potential donor's relatives has been identified as an essential step in acquiring organ donors. Therefore, the health care professionals in charge of this challenging conversation should be supported through suitable educational trainings in order to be able to talk competently and sensitively with the next of kin. Personal skills, experiences, and communication style are very important components. Trust in the physician as well as satisfaction with the received care in the hospital makes a pro-organ decision more likely. With regards to the family refusal rate, it is obvious that Spain has the lowest of all three countries. The communication policy in Spain consists of more measures than the sole deployment of transplant coordinators and it is a challenging task to successfully interconnect the different measures with each other. It is only a strategic multilevel communication policy that generates a positive attitude towards organ donation in the hospitals and creates awareness in the society. Appropriate enlightenment of society together with the elimination of prejudices is important points for an increase in the organ donation rate. On the national level, Spain has a systematic approach with a clear focus on direct media involvement with first-hand meetings. Germany focuses more on the involvement of the healthcare network (health insurers) and on national awareness campaigns. A similar approach in Austria is currently not visible. Furthermore, Germany and Spain also have a 24-hour telephone helpline for the general public.

\section{Conclusion}

For a successful adaption of the Spanish model, a few factors are a pre-requsite in the respective country namely: An established public national health system with equal access for each inhabitant, a certain amount of economic health care resources, and a sufficient funding which includes the reimbursement of the local hospital expenses for organ procurement, transplantation, and political support (Matesanz, 2003, pp. 738-740). Most of these requirements are already existent in Austria as well as in Germany but as it has been shown in this paper, a holistic strategic communication policy on the (inter)personal and national level is still missing or could be improved. It is evident that with regard to influencing factors that determine the organ donor rate, this contribution is not exhaustive. Collecting data in one country and in addition in the context of a cross-country analysis is difficult because of sparse (comparable) data. There might be other direct or indirect influencing 
factors than communication, which still might not have been taken into consideration or analysed into depth (Irving, Tong, Jan, Cass, Rose, Chadban, ... Howard, 2011). It would be interesting to conduct a survey in the European Union to explore the general attitude of the European citizens. Furthermore, the role of new technologies as an important information tool for more personal and interactive communication in the sense of a two-way dialogue would make sense to be analysed in further studies. Above all, this paper has to be seen as the first step in a comparative analysis of a complex field of organ transplantation, involving different stakeholders on a national, regional, and local level. It would be beneficial for Germany and Austria to establish an international cooperation arrangement with Spain in order to get support and advice with respect to Spain's communication policy. Even if a country may like to adopt the Spanish model, it is not certain that they will face the same success owing to the structural and demographic differences between nations. Nevertheless, Some countries like Portugal, Croatia, and Italy in Europe but also Argentine and Australia adopted either the complete Spanish model or just parts of it and some of them have been more fruitful, some less. However, each approach is important to offer the chance of a transplant to as many patients as possible at a global level.

\section{References}

Ärzte Zeitung. (2014). Kampagne'Ich entscheide'gestartet. Retrieved from http://www.aerztezeitung.de/politik_gesellschaft/organspende/article/862571/organspende-kampagne-entscheide-gestartet.ht $\mathrm{ml}$

Australian Government. (2013). Organ and Tissue Authority. Retrieved from http://www.donatelife.gov.au/sites/default/files/OTA_Fact_Sheets_-_International_approaches_to_organ_donation_reform_ November_2013.pdf

Bouwman, R., Lie, J., Bomhoff, M., \& Friele, R.D. (2013). Study on the set-up of organ donation and transplantation in the EU member states, uptake and impact of the EU action plan on organ donation and transplantation (2009-2015). Utrecht: Nivel. Retrieved from http://ec.europa.eu/health/blood_tissues_organs/docs/organs_actor_study_2013_en.pdf

Bundesministerium für Gesundheit und Frauen. (2016). ÖBIG-Transplant Annual Report 2015. Gesundheit Österreich GmbH Vienna. Retrieved from http://www.goeg.at/cxdata/media/download/berichte/kurzfassungorganspende2015.pdf

Bundeszentrale für gesundheitliche Aufklärung. (n.d.). Gesetz zur Regelung der Entscheidungsordnung. Köln: BZgA. Retrieved from https://www.organspende-info.de/infothek/gesetze/entscheidungsl\%C3\%B6sung)

Bundeszentrale für gesundheitliche Aufklärung. (2012). Wie ein zweites Leben. Informationen der Bundeszentrale für gesundheitliche Aufklärung (BZgA) zur Organ- und Gewebespende. Köln: BZgA.

Bundeszentrale für gesundheitliche Aufklärung. (2014). Repräsentativbefragung: Einstellung, Wissen und Verhalten der deutschen Allgemeinbevölkerung zur Organ- und Gewebespende. Köln: BZgA. Retrieved from http://www.dso.de/uploads/tx_infoc/BZGA_Umfrage_2014_2.pdf

Council of Europe. (2013). Background \& $\quad$ Mission. $\quad$ Retrieved from http://www.edqm.eu/en/organ-transplantation-mission-67.html

Council of Europe. (2014, October 6). European Day for organ donation. Retrieved from http://www.coe.int/en/web/portal/12-october-european-day-for-organ-donation

Deutsche Stiftung Organtransplanation. (n.d.a). Zahlen zur Organspende und Transplantion. Retrieved from

http://www.dso.de/servicecenter/downloads/grafikgalerien.html

Deutsche Stiftung Organtransplantation. (DSO). (n.d.b). Tätigkeitsprofil: Organspende-Koordination. Retrieved from http://www.dso.de/dso/arbeitsplatz-dso/taetigkeitsprofil-organspende-koordination.html

Deutsche Stiftung Organtransplantation. (DSO). (2012). Organ Donation and Transplantation in Germany 2012. Retrieved from

http://www.dso.de/uploads/tx_dsodl/DSO_JB_D_2012_e.pdf

Deutsche Stiftung Organtransplantation. (DSO). (2014). Organspende und Transplantation in Deutschland. Jahresbericht 2013.

Frankfurt: DSO. Retrieved from http://www.dso.de/uploads/tx_dsod1/JB_2013_Web_b.pdf

Eurotransplant. (n.d.). About Eurotransplant. https://www.eurotransplant.org/cms/index.php?page=about_brief 
Febrero, B., Ríos A., Martínez-Alarcón, L., López-Navas, A., Sánchez, J., Ramis, G., ...Parrilla, P. (2013). Knowledge of the brain death concept among adolescents in Southeast Spain. Transplantation Proceedings, 45, 3586-3588. Retrieved from http://www.ncbi.nlm.nih.gov/pubmed/24314966

Gevers, S., Janssen, A., \& Friele, R. (2004). Consent systems for post mortem organ donation in Europe [Abstract]. European Journal of Health Law, 11, 175-186. Retrieved from http://www.ncbi.nlm.nih.gov/pubmed/15387424?dopt=Abstract

Global Observatory on Donation and Transplantation. (2006). Retrieved from http://www.transplant-observatory.org/Pages/home.aspx

Irving, M.J., Tong, A., Jan, S., Cass, A., Rose, J., Chadban, S.,...Howard, K. (2011). Factors that influence the decision to be an organ donor: a systematic review of the qualitative literature. NDT Nephrol Dial Transplant, 0, 1-8. doi: 10.1093/ndt/gfr683. Retrieved from http://ndt.oxfordjournals.org/content/early/2011/12/21/ndt.gfr683.full.pdf+html

Lippincott Williams \& Wilkins, Inc. (2011). The Madrid resolution on organ donation and transplantation. National responsibility in meeting the needs of patients, guided by the WHO principles. Transplantation, 91, S29-S31. Retrieved from http://journals.lww.com/transplantjournal/Fulltext/2011/06151/The_Madrid_Resolution_on_Organ_Donation_and.4.aspx

Martínez, J. M., López, J. S., Martín, A., Martín, M. J., Scandroglio, B., \& Martín, J. M. (2001). Organ donation and family decision-making within the Spanish donation system. Social Science \& Medicine, 53, 405-421. Retrieved February 02, 2014, from http://www.ncbi.nlm.nih.gov/pubmed/11459393

Matesanz, R. (2003). Factors influencing the adaption of the Spanish Model of organ donation. Transplant International, 16 (10), 736-741. Retrieved from http://onlinelibrary.wiley.com/store/10.1111/j.1432-2277.2003.tb00233.x/asset/j.1432-2277.2003.tb00233.x.pdf?v=1\&t=huk x0nrw\&s=0b08190ecefb61d2db6f5c2017c0cc1e9746297b

Matesanz, R., Domínguez-Gil, B., Coll, E., De la Rosa, G., \& Marazuela, R. (2011). Spanish experience as a leading country: What kind of measures were taken? Transplant International, 24, 333-343. Retrieved from http://onlinelibrary.wiley.com/doi/10.1111/j.1432-2277.2010.01204.x/full

OEBIG-Transplant. (n.d.). OEBIG-Transplant. Gesundheit Österreich GMBH. Retrieved from http://www.goeg.at/en/OeBIG-Transplant

Organización Nacional de Transplant. (n.d.). Área de prensa. Retrieved from http://www.ont.es/prensa/Paginas/default.aspx

Poepplein, A. A. (2012). The Spanish Model of family interviewing on organ donation: An option for Germany to decrease rejection rates? Transplantation, $94 \quad$ (10S), $524 . \quad$ Retrieved from http://journals.lww.com/transplantjournal/Citation/2012/11271/The_Spanish_Model_of_Family_Interviewing_on_Organ.10 09.aspx

Rodríguez-Arias, D., Wright, L., \& Paredes, D. (2010). Success factors and ethical challenges of the Spanish Model of organ donation. The Lancet, $\quad 376, \quad 1109-1112 . \quad$ Retrieved from http://www.thelancet.com/journals/lancet/article/PIIS0140-6736(10)61342-6/fulltext

Rudge, C, Matesanz, R., Delmonico, F.L. and Chapman, J. (2012). International practices of organ donation. British Journal of Anaesthesia 108 (s1): i48-i55. Retrieved from http://bja.oxfordjournals.org/content/108/suppl_1/i48.long

Siminoff, L. A.; Traino, H. M.; Genderson, M.W. (2015 ). Communicating Effectively about Organ Donation: A Randomized Trial of a Behavioral Communication Intervention to Improve Discussions about Donation. Transplantation Direct, March 2015, Vol 1, Issue 2, p.1-9, DOI 10.1097/TXD.0000000000000513. Available at: http://journals.lww.com/transplantationdirect/Fulltext/2015/03000/Communicating_Effectively_About_Organ_Donation_ A.6.aspx\#

Spooner, M. H. (2003). More countries hoping to copy Spain's organ-donation success. Canadian Medical Association Journal, 169, 952. Retrieved from http://www.ncbi.nlm.nih.gov/pmc/articles/PMC219643/

Smith, R. D. (2013). Strategic Planning for Public Relations. $4^{\text {th }}$ ed. New York: Routledge. 